JOURNAL OF SECURITY AND SUSTAINABILITY ISSUES

ISSN 2029-7017 print/ISSN 2029-7025 online

2020 September Volume 10 Number 1

https://doi.org/10.9770/jssi.2020.10.1(2)

Scopus

\title{
MECHANISM OF STATE ECONOMIC SECURITY MANAGEMENT IN THE DIRECTION OF INTELLECTUAL PROPERTY RIGHTS PROTECTION: CASES OF SELECTED INDUSTRIES
}

\author{
Alexander Baranov $^{1 *}$, Vitalii Kucher ${ }^{2}$, Olena Ustymenko ${ }^{3}$, Maryna Utkina ${ }^{4}$, Iryna Hrybachova ${ }^{5}$ \\ ${ }^{1 *}$ Center for Social and Legal Issues in the sphere of information technologies, products and services. \\ 110-c str. Saksaganskogo, Kyiv, 01032, Ukraine; \\ ${ }^{2}$ Lviv State University of Internal Affairs Lviv, Gorodotska, 16, 79007, Ukraine \\ ${ }^{3}$ V.N. Karazin Kharkiv National University, Freedom Square, 4, Kharkiv, 61000, Ukraine \\ ${ }^{4,5}$ Sumy State University, 2 Rimsky-Korsakova Street, Sumy, 40000, Ukraine \\ E-mail: ${ }^{1 * k o a d u e p @ g m a i l . c o m ~(C o r r e s p o n d i n g ~ a u t h o r) ~}$
}

Received 20 January 2020; accepted 10 June 2020; published 30 September 2020

\begin{abstract}
The article is dedicated to the research of legal and management aspects of intellectual property rights protection in the field of medicine and biotechnologies. The authors clarified the patenting peculiarities of inventions in the area of medicine and biotechnologies, particularly issues concerning applications for obtaining patents, the determination of intellectual property compliance with patentability requirements, the registration of granted patents in the relevant registry etc. They identified the legal and organizational aspects of intellectual property rights protection in the field of medicine and biotechnologies upon the study of the leading European countries experience (using the examples of the United Kingdom, Germany and France). One summarized the international experience in the protection of intellectual property rights in the field of medicine and biotechnologies and highlighted the regulation specifics of these issues according to the current Ukrainian legislation. In particular, the authors defined the requirements for the protection of intellectual property rights in the field of medicine and biotechnologies, which have been set out in legal documents at the international level. Recommendations for management organization and intellectual brand capital protection depending on specificity of national economic and legal model. Are offered. The mechanism of economic security management of a country for intellectual property right protection in the field of medicine and biotechnologies is created.
\end{abstract}

Keywords: economic and legal security; management of intellectual brand capital; intellectual property; biotechnology; medicine; invention; patent

Reference to this paper should be made as follows: Baranov, A., Kucher, V., Ustymenko, O., Utkina, M., Hrybachova, I. 2020. Mechanism of state economic security management in the direction of intellectual property rights protection: cases of selected industries. Journal of Security and Sustainability Issues, 10(1), 19-34. https://doi.org/10.9770/jssi.2020.10.1(2)

JEL Classifications: F35; F42

\section{Introduction}

Nowadays, in the presence of fleeting globalization processes, the world system of intellectual property rights protection is almost formed (Sagiyeva et al, 2018; Zeibote et al., 2019; Chehabeddine, Tvaronavičienè, 2020; Lincényi, Čársky, 2020; Danko et al, 2020). This means that, in many countries around the world the efforts of governments to protect intellectual property rights are aimed at creating regulatory framework, which would offer guarantees and effective mechanisms for such protection. The significance of intellectual property rights protection matter is explained by the fact that, in the light of global development, the economics intellectualization process takes place. In the end, such a phenomenon influences the economic security of a particular country. 
The world trends of economic and technological development require the adjustment of legislation, that is to say, bringing laws and other regulatory instruments in line with world requirements and standarts in the sphere of intellectual property rights protection. With the ratification of the Ukraine-EU Association Agreement in 2014 our State made a commitment to approximate national legal system to EU legislation in the field of intellectual property. Therefore, to define strategic goals in reforming of intellectual property field became top priority. In this context, the subject matter of intellectual property rights protection in the field of medicine and biotechnologies is not an exception, and that is why it needs more detailed research.

\section{Literature Survey}

In order to study the features of intellectual property rights protection in the field of medicine and biotechnologies, it is appropriate to analyze the experience of leading European countries on their governments' regulation of such issues, as well as legal and organizational aspects of providing this protection. It is important to clarify that, intellectual property rights protection in most of the countries is carried out by means of patenting inventions in this area. For this purpose, patent laws and regulations of a particular country are applied.

This way, the key provisions of patent law in the United Kingdom are stated in The Patents Act, which was adopted back in 1977. In the branch of medicine and biotechnologies, an element isolated from the human body or otherwise produced by means of technical process, including the sequence or partial sequence of a gene, may constitute a patentable invention, even if the structure of that element is identical to that of a natural element. However, the law clearly states that, the application for such a patent must necessarily reveal the industrial use of the sequence or partial sequence of a gene. Any person may apply for a patent either alone or jointly with another. Each patent application is made in the prescribed form and filed at the Patent Office in the prescribed manner. It also provides for the payment of patent fee. As soos as it is possible after the patent has been granted, the controller will publish a notice in the journal about its issuance, the specification of the patent, as well as names of the owner and the inventor (if they are different), and any other information concerning the patent, which the controller deems appropriate to publish. The patent is valid for 20 years, starting from the date of filing the application for the patent or another date, which may be prescribed (The Patents Act, 1977). Enshrined in The Patents Act of 1977, the general principles of patenting have been specified in The Patents Rules of 2007 and, therefore, defined the detailed patenting procedures.

The main official government body, responsible for legal protection of inventions in the United Kingdom is The Intellectual Property Office (IPO), which is subordinated to the Department for Business, Innovation \& Skills (BIS). The IPO is regulated by The Patents Act of 1977 and The Patents Rules of 2007 in its work. In addition, 15 Patent Library Centres are located in the United Kingdom to provide addressing a variety of intellectual property issues (UK PatLib contact information).

The issues of legal protection of intellectual property in Germany are regulated by two main legal acts: The Patents Act (Patentgesetz (PatG)) of 1980 and The Patent Costs Act (Patentkostengesetz (PatKostG)) of 2001. The Patents Act defines the list of objects protected by patents, the procedure for obtaining patents, along with the structure and functions of the Patent Office and the Patent Court. The patent is valid for 20 years starting from the day, which follows the application date. It is important to note the restrictions on the granting of patents for inventions set by Section 2 of The Patents Act. No patents shall be granted for inventions, the commercial exploitation of which would be contrary to public order or morality. In particular, patents shall not be granted for:

- processes for cloning human beings;

- processes for modifying the germ line genetic identity of human beings;

- uses of human embryos for industrial or commercial purposes;

- processes for modifying the genetic identity of animals, which are likely to cause them suffering without any substantial medical benefit to man or animal, and also animals resulting from such processes (Patentgesetz (PatG), 1980). 
The Patent Office is an independent supreme federal authority within the Federal Ministry of Justice and Consumer Protection. The Patent Office is composed of the President and other members, appointed for life. The Patent Office contains the examiner's offices, which process patent applications and inform about the status of their examination, as well as patent agencies for all the issues, related to the granting of patents and legal assistance in case of disputes (Patentgesetz (PatG), 1980).

The legislation of France, which regulates the issues of the legal protection of intellectual property rights, including the field of medicine and biotechnologies, has been codified and presented by The Intellectual Property Code (Code de la propriété intellectuelle) of 1992. The peculiar feature of current French patent laws is that, they distinguish the regulation of biotechnological products from the regulation of traditional inventions. Art.611-18 of The Code determines the fact that, the human body at the various stages of its formation and development, along with the simple discovery of one of its elements, including complete or partial sequence of a gene, cannot constitute patentable inventions. Only that invention, which is a technical use of the function of human body element, may be protected by patent. This protection covers only the element of human body to the extent, necessary for the implementation and harnessing of this particular application. This should be specifically and accurately explained in the patent application. In particular, the following are not patentable: a) processes for cloning human beings; b) procedures for modifying the genetic identity of humans; c) uses of human embryos for industrial or commercial purposes; d) complete or partial sequence of a gene per se (Code de la propriété intellectuelle, 1992).

The legal body responsible for granting patents for inventions is The National Institute of Industrial Property (L'Institut national de la propriété industrielle (INAPI)), which is under authority of the Ministry of Economy, Industry and Digital Technologies. INAPI implements the national policy on industrial property; facilitates public acess to technical data about all the documents and information concerning their sphere of examination; assists, develops and enhances inventive and innovative abilities with the help of both material and moral incentives. Beside the regulations of The Intellectual Property Code, the legal basis of INAPI's work for the protection of intellectual property rights in the field of medicine and biotechnologies is constituted by:

- The Regulation № 03-07 on patents for the invention of 2003;

- The Executive Decree № 05-275, which determines the procedure of filing applications and granting patents for the invention of 2005;

- The Executive Decree № 76-121 on Procedures for Registration and Publication of Geographical Indications and the Establishment of the Relevant Fees of 1976 (The official website of the L'Institut national de la propriété industrielle, INAPI).

\section{Methods}

The research of the legal and organizational aspects of intellectual property rights protection in the field of medicine and biotechnologies was performed using epistemological method, system-structural method, and comparative law-based analysis.

The epistemological method of research made it possible to find out the peculiarities of patenting inventions in the field of medicine and biotechnologies. That is, in particular, ones concerning patent applications, the confirmation of intellectual property compliance with patentability requirements, the registration of granted patents in the relevant registry, etc.

Upon the study of the leading European countries experience (using the examples of the United Kingdom, Germany, France) due to the system-structural method of research one defined legal and organizational aspects of intellectual property rights protection in the field of medicine and biotechnologies.

The comparative law-based analysis was applied to summarize the international experience in protection of intellectual property rights in the field of medicine and biotechnologies, as well as to highlight the regulation specifics of these issues in accordance with the current Ukrainian legislation. This method was likewise used to 
identify requirements for the protection of intellectual property rights in the field of medicine and biotechnologies, which are laid down in international legal documents, as well as the peculiarities of international organizations activities, the function of which relates to the protection of intellectual property rights in the research area.

\section{Results}

The protection of intellectual property rights in the field of medicine and biotechnologies at the international level is carried out in accordance with the requirements of regulatory legal documents. Special attention should be paid to the provisions of the Convention on Biological Diversity of 1992; the European Patent Convention of 1973; the Directive 1998/44/EC of the European Parliament and of the Council of 1998 on the legal protection of biotechnological inventions; the Convention for the protection of Human Rights and Dignity of the Human Being with regard to the Application of Biology and Medicine: Convention on Human Rights and Biomedicine of 1997; The Agreement on Trade-Related Aspects of Intellectual Property Rights (TRIPS) of 1994 between the member nations of the World Trade Organization.

The definition of the term «biotechnology» first found its regulation in the Convention on Biological Diversity, and therefore, was enshrined in the legal document at the international level. Art. 2 explains biotechnology as any technological application that uses biological systems, living organisms or derivatives thereof, to make or modify products or processes for specific use (Convention on Biological Diversity, 1992).

According to the European Union law the legal protection of intellectual property in the field of biotechnologies is implemented by means of patenting inventions in this area. The relevant provisions of the Directive 98/44/EC of the European Parliament and of the Council of 1998 on the legal protection of biotechnological inventions confirm this fact. Art. 1 of the Directive 98/44/EC obliges EU member states to protect biotechnological inventions under national patent law. However, if necessary, EU member states have a right to adjust their national patent law to take account of the provisions of the Directive 98/44/EC. Art. 3 of the Directive 98/44/EC defines the requirements for patenting new inventions. In particular, it is noted, that inventions which are new, which involve an inventive step and, which are susceptible of industrial application shall be patentable. Even if they concern a product consisting of or containing biological material or a process by means of which biological material is produced, processed or used. Plant and animal varieties, as well as essentially biological processes for the production of plants and animals, shall not be patentable, as indicated in Art. 4 of the Directive 98/44/EC (Directive 98/44/EC, 1998).

According to the Directive 98/44/EC, human organism, at the various stages of its formation and development, and the simple discovery of one of its elements, including the sequence or partial sequence of a gene, cannot constitute patentable inventions. On the other hand, an element isolated from the human body or otherwise produced by means of a technical process, including the sequence or partial sequence of a gene, may constitute a patentable invention, even if the structure of that element is identical to that of a natural element (Directive 98/44/EC, 1998). Thus, the provisions of the Directive 98/44/EC differentiated intellectual property objects into patentable ones and those, which cannot constitute patentable inventions because of some particular features.

The specific peculiarities of intellectual property protection in the field of biotechnologies by means of patents are given in Chapter II of the Directive 98/44/EC. The protection conferred by a patent on a biological material possessing specific characteristics as a result of the invention shall extend to any biological material derived from that biological material through propagation or multiplication in an identical or divergent form and possessing those same characteristics (Directive 98/44/EC, 1998).

The European Patent Convention of 1973 defined patentable objects of intellectual property. As to the intellectual property rights protection in the field of medicine and biotechnologies, the following should be mentioned: according to Art. 53 of the Convention, European patents are not granted for 1) plant or animal varieties and essentially biological processes for the production of plants and animal; 2) methods for treatment of the human or animal body by surgery or therapy, and diagnostic methods practised on the human or animal body (European Patent Convention, 1973). 
The Convention for the protection of Human Rights and Dignity of the Human Being with regard to the Application of Biology and Medicine: Convention on Human Rights and Biomedicine of 1997 states that, any health-related intervention, including scientific research, may only take place in accordance with corresponding professional duties and standarts (Convention on Human Rights and Biomedicine, 1997).

The World Trade Organization (WTO) (membership of Ukraine since 2008) is guided by the legal document, which regulates the issues of intellectual property rights protection in the field of medicine and biotechnologies, and that is - the Agreement of Trade-Related Aspects of Intellectual Property Rights (TRIPS). TRIPS entitles members to exclude from patentability inventions, the prevention within their territory of the commercial exploitation of which is necessary to protect ordre public or morality, including the security of human, animal or plant life and health or to avoid serious prejudice to the environment (part 2 Art. 27 TRIPS). Along with that member nations of TRIPS may also prohibit patenting certain forms of life (plants and animals), but they shall provide patent protection of specific plant varieties, micro-organisms, non-biological and microbiological processes (parag. b part 3 Art. 27 TRIPS) (WTO: Agreement of Trade-Related Aspects of Intellectual Property Rights, 1994).

The international organizations dealing with the protection of intellectual property rights are The World Intellectual Property Organization (WIPO), the European Patent Office (EPO) and the European Union Intellectual Property Office (EUIPO).

The World Intellectual Property Organization (WIPO) is an international intergovernmental organization, created in accordance with the Convention adopted in 1967 by member states of the Paris Union for the Protection of Industrial Property, the Berne Union for the Protection of Literary and Artistic Works, and other special unions. The International Bureau of WIPO (the Secretariat) has been located in Geneva since 1974, when WIPO acquired the status of the Specialized agency of the United Nations (The official website of WIPO).

The European Patent Office (EPO) is ingovernmental body, which works under the legal basis of the European Patent Convention. From 16 member states, who signed The European Patent Convention of 1973, the organization has grown up to 38 members, including all 28 member states of the EU plus such states as Norway, Switzerland and Turkey. EPO studies European patent applications, thereby giving a chance to all inventors, researchers and companies worldwide to protect their inventions in almost 44 countries by means of a centralized and single patent grant procedure, which involves a simplified procedure - filing only one application. EPO performs the search and thorough examinations of constantly growing number of European patent applications and international patent applications, filed in line with the Patent Cooperation Treaty. The disclosure of invention and subsequent publication are fundamental for the European patent system. The European Publication Server is a source, where the public can get the official copies of European patent documents. The European Patent Register provides detailed procedural information on all patent applications (The official website of the EPO).

Among many different types of patents, EPO also issues biotechnological patents. Biotechnology is explained as the use of biological processes, organisms, or systems to manufacture products intended to improve the quality of human life. Inventors have been filing applications for biotechnology patents for over a hundred years. Biotechnology is an important industrial sector for the European economy, providing employment and growth for European society and countless useful medical and other products for its citizens. It covers a vast field ranging from medical and pharmaceutical products (55\% of all patents in biotechnology) to industrial processes (41\%) and agriculture, which comprises just 4\%. (Biotechnology patents at the EPO).

Patents are crucial for promoting medical progress. Advances in the life sciences and pharmaceutical sector have had an impact on life expectancy and the quality of life. That is explained by the fact, that most modern medicines are based on biotechnologies. One of the earliest biomedicaments was insulin, a life-saving drug for diabetics. Other patented medical inventions have provided breakthroughs in DNA fingerprinting, paternity testing and blood transfusions, where patented tests to check donated blood for the presence of deadly viruses have improved patient safety. Many anti-cancer drugs based on patented human gene sequences are prolonging 
the lives of cancer patients. Governments can counter a perceived abuse of a patent monopoly by, for example, granting a compulsory licence against a patent holder to enable generics companies to sell the same product more cheaply, negotiating with patent holders to reduce the price of patented medicines, and using competition laws.

Patents are an effective barrier to illicit copying of medicines and the health risks. Patents constitute a limited exclusive right only: once the patent has expired (after a maximum of 20 years), the invention falls in the public domain and can be used by anyone without paying royalties. National authorities work with pharmaceutical companies to negotiate lower prices for medical products, and after the patent has expired, cheaper generic copies may enter the market. The patent system also creates transparency: patent applications are published 18 months after filing, so they disclose detailed information about the latest technical improvements. Like plants, animals are patentable according to the law. The patent applications filed with the EPO mostly concern transgenic (genetically modified) mice and rats used in medical research. However, the EPO takes ethical considerations into account: if the transgenic invention is found to make the animal suffer, it may only be patented if it brings a substantial medical benefit to humans (or animals) (Biotechnology patents at the EPO).

On March 15, 2019 the Eurasian Patent Office (EAPO) announced the signing of collaborative agreement with the Medicines Patent Pool (MPP) on accessing the legal status patent information of the Eurasian patent applications and granted Eurasian patents for pharmaceutical inventions. The aim of this cooperation is to enable interested parties to carry out their activities in developing or supplying medicines to the market without violating the rights of owners of Eurasian patents.

It is worth to mention, that The European Union Intellectual Property Office (EUIPO), known as OHIM until March 23, 2016, is operating to provide the protection of intellectual property rights throughout the EU. EUIPO administers the EU Trade Mark and Design rights, and since 2012 has also been responsible for the Observatory on the Infringement of Intellectual Property Rights and the Orphan Works Database. EUIPO works closely with the European Patent Office (EPO) and the World Intellectual Property Organisation (WIPO), as well as with another representative offices dealing with intellectual property matters in the EU and international partners to develop suggestions for the use of trade mark and design registration experience in Europe and worldwide. EUIPO is a decentralized EU Agency, which constantly cooperates with the European Commission and its Directorate-General for Internal Market, Industry, Entrepreneurship and SMEs (GROW). EUIPO has legal, administrative and financial autonomy over staffing and budgetary matters. EUIPO is governed by the Management Board and Budget Committee, comprising:

- 1 representative per EU country;

- 1 representative from the European Parliament;

- 2 representatives from the European Commission (The official website of the EUIPO).

Apart from international organizations WIPO, EPO and EUIPO, which protect intellectual property rights in the field of medicine and biotechnologies by means of granting patents, there also exists the Unified Patent Court (UPC), where one can apply in case of violation of these rights. UPC, established on February 19, 2013, has exclusive jurisdiction over litigation on the infringement and the invalidation (revocation) of European patents and EU unitary patents, as well as litigation on the infringement and the validity of supplementary protection certificates - documents, certified on basis of the Regulation (EC) № 469/2009 of the European Parliament and of the Council of May 6, 2009 concerning the supplementary protection certificate for medicinal products or the Regulation (EC) № 1610/96 of the European Parliament and of the Council of July 23, 1996 concerning the creation of a supplementary protection certificate for plant protection products. The legal framework of UPC functioning is presented in the Agreement on a Unified Patent Court, according to which the Court has exclusive competence in respect of:

(a) actions for actual or threatened infringements of patents and supplementary protection certificates and related defences, including counterclaims concerning licences;

(b) actions for declarations of non-infringement of patents and supplementary protection certificates;

(c) actions for provisional and protective measures and injunctions; 
(d) actions for revocation of patents and for declaration of invalidity of supplementary protection certificates;

(e) counterclaims for revocation of patents and for declaration of invalidity of supplementary protection certificates;

(f) actions for damages or compensation derived from the provisional protection conferred by a published European patent application;

( $\mathrm{g}$ ) actions relating to the use of the invention prior to the granting of the patent or to the right based on prior use of the invention;

(h) actions for compensation for licences;

(i) actions concerning decisions of the European Patent Office (Agreement on a Unified Patent Court, 2013).

One of the key elements in the Ukraine-EU Association Agreement of 2014 was the security and protection of intellectual property rights, including the field of medicine and biotechnologies. The key principles of cooperation in this area are set out in Chapter 9, Title IV, «Intellectual Property». Art. 221 defined the main rule, according to which the protection of biotechnological inventions is implemented by parties under national patent law. However, if necessary, they may adjust their patent law to take account of the provisions of the Agreement.

Serious attention needs to be paid to defining the patentability of intellectual property objects in the field of medicine and biotechnologies. Inventions, which concern plants or animals shall be therefore patentable if their technical feasibility is not confined to a particular plant or animal variety. Inventions shall be considered unpatentable if their commercial exploitation is contrary to ordre public (public order) or public morality. The following shall be considered unpatentable:

a) processes for cloning human beings;

b) processes for modifying the germ line genetic identity of human beings;

c) uses of human embryos for industrial or commercial purposes;

d) processes for modifying the genetic identity of animals, which are likely to cause them suffering without any substantial medical benefit to man or animal, and also animals resulting from such processes (Association Agreement, 2014).

The protection conferred by a patent on a biological material possessing specific characteristics as a result of an invention shall extend to any biological material derived from that biological material through propagation or multiplication in an identical or divergent form and possessing those same characteristics. The protection conferred by a patent on a process that enables a biological material possessing specific characteristics to be produced as a result of an invention shall extend to biological material directly obtained through that process and to any other biological material derived from the directly obtained biological material through propagation or multiplication in an identical or divergent form and possessing those same characteristics. The protection conferred by a patent on a product containing or consisting of genetic information shall extend to all material (Association Agreement, 2014).

The Agreement also defines cases when cross-licensing is compulsory. They are, in particular:

a) where a breeder cannot acquire or exploit a plant variety right without infringing a prior patent, he/she may apply for a compulsory licence for non-exclusive use of the invention protected by the patent inasmuch as the licence is necessary for the exploitation of the plant variety to be protected, subject to payment of an appropriate royalty. The parties shall provide that, where such a licence is granted, the holder of the patent will be entitled to a cross-licence on reasonable terms to use the protected variety;

b) where the holder of a patent concerning a biotechnological invention cannot exploit it without infringing a prior plant variety right, he/she may apply for a compulsory licence for non-exclusive use of the plant variety protected by that right, subject to payment of an appropriate royalty. The parties shall provide that, where such a licence is granted, the holder of the variety right will be entitled to a cross-licence on reasonable terms to use the protected invention. 
Applicants for the licences referred to in paragraph 11 of this Article must demonstrate that:

a) they have applied unsuccessfully to the holder of the patent or of the plant variety right to obtain a contractual licence;

b) the plant variety or the invention constitutes significant technical progress of considerable economic interest compared with the invention claimed in the patent or the protected plant variety (Association Agreement, 2014).

Thus, under the current Ukraine-EU Association Agreement, the protection of intellectual property in the field of medicine and biotechnologies needs harmonization of the national legislation with the requirements of the EU law. At the same time, bringing Ukrainian patent law system of intellectual property protection up to the European standarts demands taking into account the interests of both biotechnology and health care providers, and society as a whole.

A detailed investigation of the legal international and national ensuring intellectual property protection requires development of an effective mechanism for economic security management of a country in order to protect intellectual property rights. Such a mechanism in the area of medicine and biotechnology should be formed according to the concept of the precisely brand capital management. The value of intellectual property for economic and legal security of a country is revealed in the process of its instrumental use. A well-known trade mark in the field of medicine and biotechnology does not appear and, most importantly, does not exist in itself, it requires purposeful continuous management (Malhotra, Y. 2003):

(1) It is a management tool with the help of which public authorities actively influence all stakeholders (customers, partners, business community) creating a certain image of a company and its products and desired behaviour of the mentioned individuals in relation to a company. In this sense a trade mark is a tool to achieve state strategic development goals.

(2) A mark is an object of management in relation to which generally accepted stages and procedures of management are applied - goal-setting, choice of strategy, evaluation of management effectiveness, etc. The elaboration of brand capital management methods for the development of economic security should be based on the study of component features of a managed object-trade marks. Being guided by a systematic approach, it is possible to formulate the main conceptual principles of organizational and economic mechanism formation of brand capital management:

1. The integrity of organizational and economic mechanism of brand capital management in which the functioning of all its parts (subsystems) and elements is directed to a general goal achievement which faces a system. In management this feature of a system is reflected in the following:

a) when there is a general unified target function of brand capital management which reflects the purpose facing a system, a target private function should be integrated for each part of a system;

b) the criteria of efficiency of a subsystem and elements functioning should maximally match the criteria of efficiency of a system in generfal (Bontis, Nick, 2001).

Accordingly, if there is the main unified target function which is separate from intellectual property objects, a target (private) function of each attribute should be also unified though a private goal achievement relating to each attribute should ensure implementation of the main target function of intellectual property objects. The complexity of an organizational and economic mechanism of brand capital management which lies in the fact that a change in any of its parts causes changes in other parts of it which are linked via a set of feedbacks (Drobyazko, et. al. 2019). For example, disadvantages in an advertising company organization lead to a decrease in sales volume and reduction in market share which can cause a rise in the product unite price in order to keep gross income in a prior volume.

Preservation at the present time and in prospect of a creative dominant role of a person in organizational and economic mechanism of brand capital management and necessity in this case to create moral and material interest in the result of system functioning. Continuity of development of organizational and economic mechanism 
of brand capital management. Interchangeability of ways to promote intellectual property objects. Influence of public authorities on brand intellectual capital through the levers of economic and socio-psychological management methods is presented in Fig. 1.

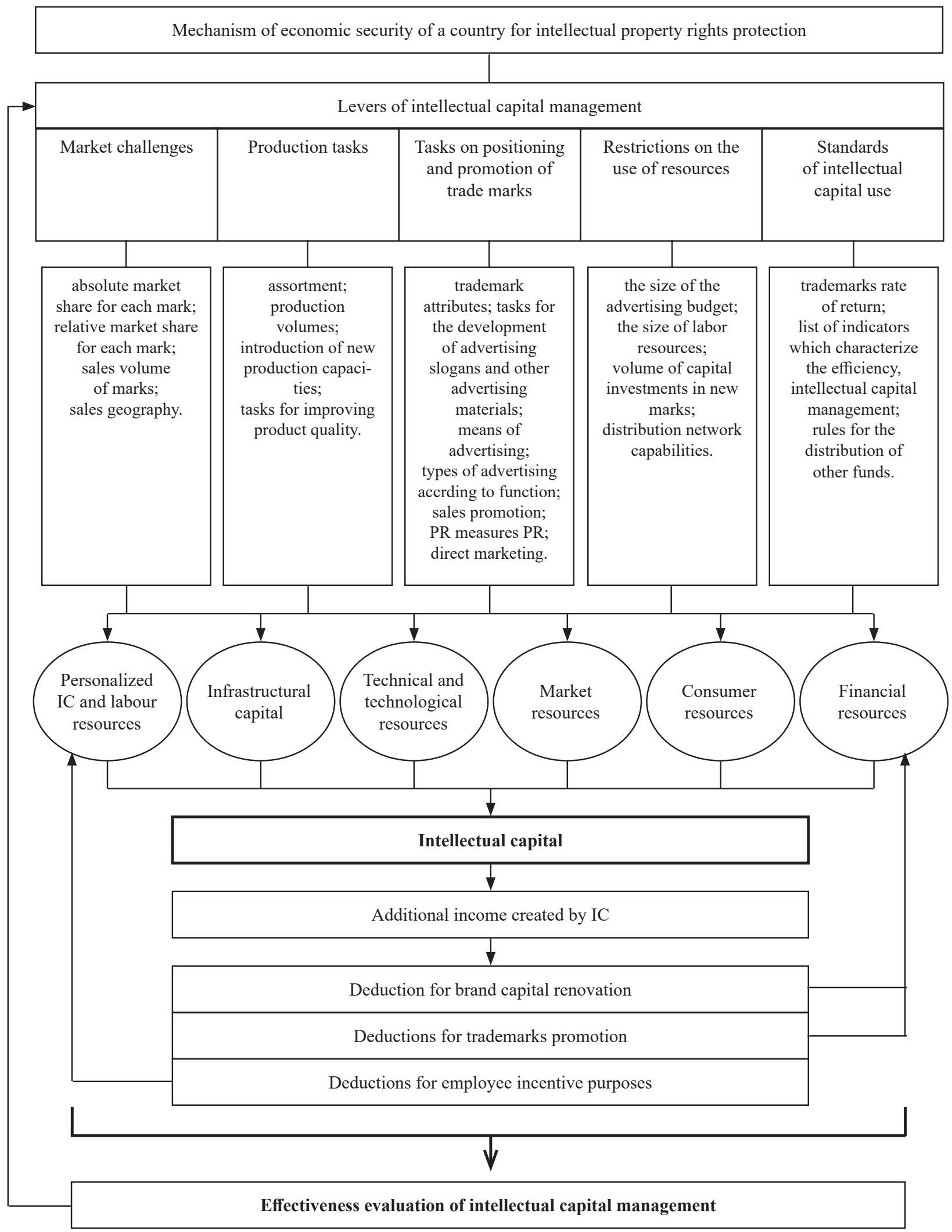

Figure 1. Mechanism of economic security management of a country for intellectual property rights protection in the area of medicine and biotechnologies 
As the problem of formation of cross-cutting efficiency criterion of brand capital management also refers to the problem of management of both a particular mark and brand capital in general, it is necessary to enumerate the approaches to studying and matching the criteria at all levels of public management.

1) The problem of a general criterion. In order to achive the optimum in a multi-brand business, it is required to have an indicator by which it is possible to determine the optimal development option or (as a last resort) some scale of advantages of possible development plans for specific trade marks.

2) Problems of a local criterion. The assessment of management of a particular brand should meet the the interests of the whole system to the maximum extent possible. Therefore, it is necessary to determine such a local criterion of optimality (if a cross-cutting one is missing) which would meet the general business interests of a company to the maximum possible extent.

3) Problems of multistage optimization. Particular ways of matching general and local solutions are required. Taking in to account the complexity of a brand capital management system (if a cross-cutting criterion is missing) such coordination is still possible only using a multistage (hierarchical) approach to optimization processes through development of iterative algorithms for linking solutions of different levels (Sullivan, P., 2000).

Being based on these methodical approaches, it is possible to formulagte a scientifically sound definition of the perfect position for economic security management in the field of intellectual brand capital. The model of perfect position of intellectual brand capital in the system of economic security of a country can be given in a form of a Fig. 2 .

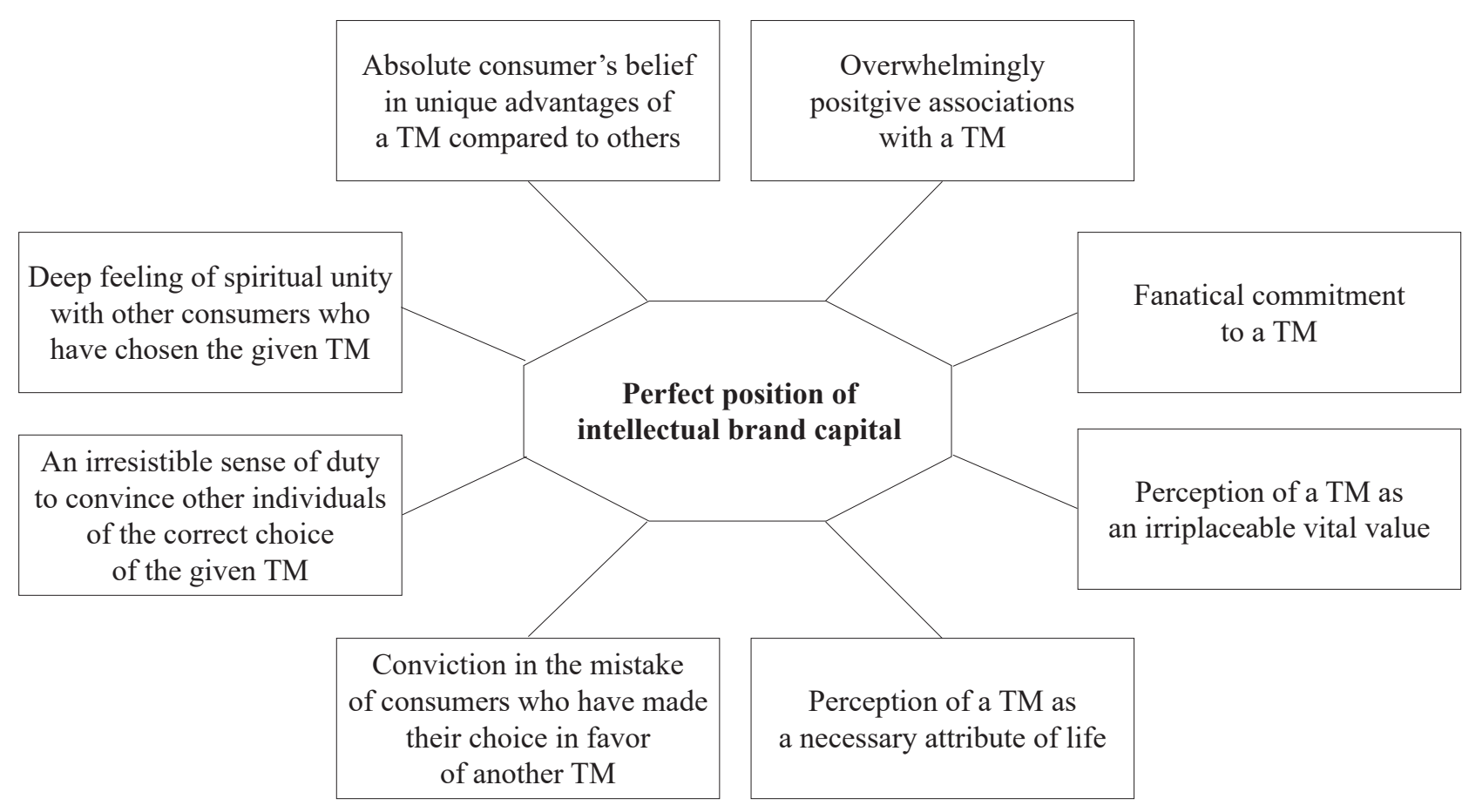

Figure 2. Model of a perfect position of intellectual brand capital positioning

A perfect position of intellectual brand capital is such its perception in an economic and legal system of a country in which an owner of a mark is absolutely sure of unique advantages of intellectual brand capital over other marks, the given brand is connected only with positive associations and it is percievd as an irreplaceable value and necessary attribute of life; perception in which a consumer is a fanatical supporter of this brand, is fully convinced that consumers who purchase goods of other marks make a wrong choice, considers it to be his duty to recommend the given brand to other consumers and feels spiritual unity with the consumers who have chosen the particular brand (Choo, C.W. and Nick Bontis, 2002).

On the basis of concept of perfect positioning of intellectual brand captal, its effectiveness can be evaluated as 
a degree of achievement of a perfect state of position parameters of intellectual property objects, that is, if we take a number of all buyers of intellectual property as $100 \%$, a graphical model of a perfect position of intellectual brand capital will be like this (Fig. 3):

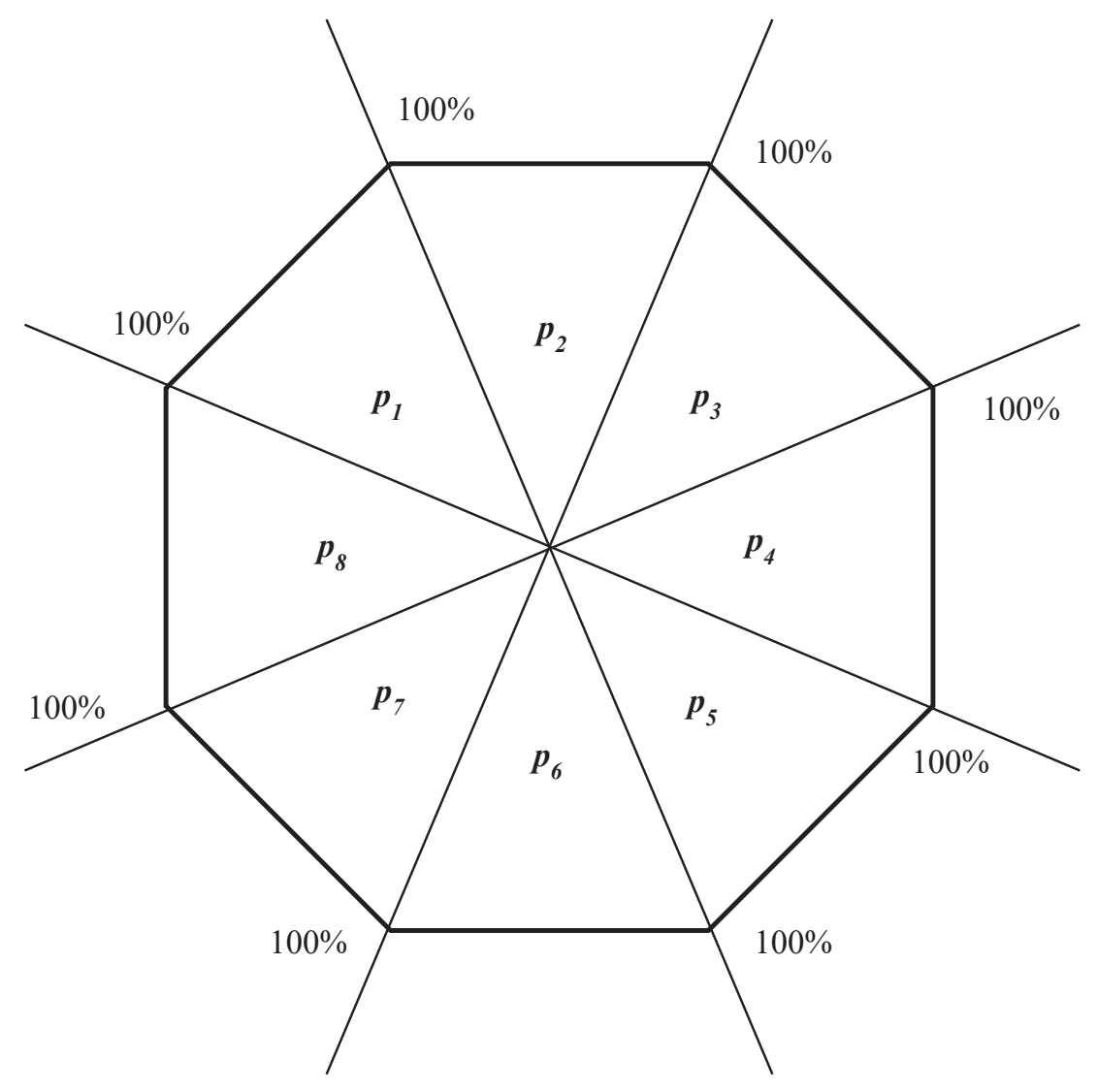

Figure 3. Graphical model of a perfect position of intellectual brand capital in the system of economic security of a country

where $p_{1}, p_{2}, p_{3}, p_{4}, p_{5}, p_{6}, p_{7}, p_{8}, p_{9,} p_{10}$ - are parameters of a position of intellectual property objects including:

$p_{1}-$ is a share (percentage) of market entities who are absolutely sure of the unique advantages of the given mark of intellectual property objects over other marks;

$p_{2}$ - is a share (percentage) of market entities who have only positive associations with the particular mark;

$p_{3}$ - is a share (percentage) of market entities who are fanatically commited to the given brand;

$p_{4}$ - is a share (percentage) of market entities who perceive a mark as an irreplaceable life value;

$p_{5}-$ is a share (percentage) of market entities who perceive a brand as a necessary attribute of life;

$p_{6}-$ is a share (percentage) of market entities who are completely convinced that the consumers who buy goods of other marks make a wrong choice;

$p_{7}-$ is a share (percentage) of market entities who consider it to be their duty to recommend the particular mark to other consumers;

$p_{8}$ - is a share (percentage) of market entities who feel spiritual unity with the consumers who have chosen the given brand.

Then the absolute effectiveness of positioning of intellectual property objects can be represented by such a formula (1):

$$
E P B=\sum_{\mathrm{i}=1}^{\mathrm{N}} a_{i} p_{i}
$$


where $p_{i}$ is a value of the $i$ parameter of an intellectual property object position (in proportions of its perfect state);

$a_{i}$ - is a coefficient of significance of the $i$ parameter of an intellectual property object position; $a_{i}=$ from 0 to $1 \sum a_{i}=1$.

Values $a_{i}$ are set according to the expert opinion.

$p_{i}-$ is set through conducting appropriate sociological researches.

Relying on benchmarking methodology, it will be more objectively to assess effectiveness of positioning on intellectual property objects in comparison with the indicators of a market brand-leader or brand-main competitor. In this case it is possible to calculate the relative efficiency of intellectual property object positioning:

$$
E P B_{r}=\frac{E P B_{a}}{E P B K_{a}}
$$

where $E P B K_{a}-$ is an absolute effectiveness of intellectual property object positioning of different market entities.

If $E P B_{r}>1$-the efficiency of intellectual property object positioning is higher than the efficiency of intellectual brand capital positioning- the strongest competitor.

Taking account of the costs on intellectual property object promotion:

$$
E P B_{r z}=\frac{E P B_{a}}{\mathrm{Z}} / \frac{E P B K_{a}}{\mathrm{Z}_{k}},
$$

where $Z$ and $Z k$-comparative costs on economic and legal security assurance respectively.

While studying the efficiency of positioning in a long-term period, it is important to assess the given indicators in dynamics for which the corresponding coefficients can be calculated:

$$
\begin{aligned}
& k_{E P B}^{1}=\frac{E P B_{r}^{t_{1}}}{E P B_{r}^{t_{0}}}, \\
& k_{E P B}^{2}=\frac{E P B_{r z}^{t_{1}}}{E P B_{r z}^{t_{0}}},
\end{aligned}
$$

wherfe $k_{E P B}^{2}$-are coefficients of dynamics of relative efficiency of intellectual property object positioning without taking into account and taking into account the costs on economic and legal security assurance, respectively.

$E P B_{r}^{t_{1}}, E P B_{r}^{t_{0}}$-is relative efficiency of intellectual property object positioning during a reporting $\left(t_{1}\right)$ and base $\left(t_{0}\right)$ periods;

$E P B_{r z}^{t_{1}}, E P B_{r z}^{t}$-relative effectiveness of intellectual property object positioning taking into account the costs on economic and legal security assurance during an accounting $\left(t_{1}\right)$ and base $\left(t_{0}\right)$ periods. 
Thus, the positioning of intellectual brand capital is a process of perception management of intellectual property objects by economic entities and legal system of a country the purpose of which is:

a) convincing a consumer of unique advantages of the given mark of intellectual property objects over other marks; b) formation of consumer's exclusively positive associations with the particular trade mark; c) formation of consumer's sense of irreplaceability and vital necessity of a given mark; d) formation of fanatical devotion to the brand; e) fostering a sense of duty to recommend a given mark to other consumers; f) fostering a sense of spiritual unity with the consumers who have chosen this particular brand; g) formation of consumer's belief thatg other consumers, who purchase goods of other marks, make the wrong choice.

In 2015 the Decree of the President of Ukraine № 5/2015 adopted the Sustainable Development Strategy «Ukraine 2020». The Strategy has envisaged the implementation of 62 state reforms and programmes in four development directions. The reform of intellectual property protection must be implemented under the direction of security (Sustainable Development Strategy «Ukraine 2020», 2015). In our opinion, carrying out the intellectual property protection reform according to the mentioned security direction is not a coincidence. Indeed, the intellectualization of economy has a significant impact on the economic security of a particular country, which ultimately affects the position of the state in the global space (Reznik et al., 2020).

Like in most European countries, the intellectual property rights protection in the field of medicine and biotechnologies in Ukraine is implemented by means of patenting inventions in this field. In particular, the current Ukrainian legislation has got The Law of Ukraine «On Protection of Rights to Inventions and Utility Models» of 1993. According to Art. 1 of the Law, invention is understood to be a result of intellectual activity of a human being in any field of technology. Patent is a protective document confirming priority, authorship and ownership right for invention. Patent for an invention is understood as a type of patent issued as a result of the qualification expert appraisal of the application for patent. In Ukraine the validity term of an invention patent is 20 years starting from the date of filing. Invention meets patentability requirements if it is new, has an inventive standard and is industrially applicable (Law of Ukraine № 3687-XII, 1993).

In Ukraine the procedure of granting patents for inventions is performed by the Institution in the field of legal protection of invention rights, that is, the State Enterprise «Ukrainian Intellectual Property Institute» (hereinafter referred to as Institution). If a person desires to obtain a patent and has a right for it, he/she shall submit an application to the Institution. The expert appraisal of an application has the status of scientific and technical examination. It consists of preliminary examination, the formal expert appraisal and, on the application for a patent, the qualification expert appraisal. The final results of the expert appraisal of the application, which is not deemed revoked and is not revoked, are presented in a substantiated conclusion of examination, which enters into force upon approval by the Institution. On the basis of such conclusion the Institution makes a decision to grant a patent or to refuse such patent. The decision of the Institution is sent to the applicant. From the date of the receipt of an application by the Institution and till the publication of the information on the application or the publication of the information on the issue of a patent, the materials of the application shall be treated as confidential information. On the basis of the decision to issue a patent the state registration of the patent takes place. For this purpose the appropriate information is entered into the Register. The form of the Register and the Register keeping procedure are determined by the Institution. The state registration of the patent for an invention is carried out upon condition that documents confirming the payment of the patent issue fee and fee for publication of the information on the issue of a patent are received. These fees should be payed after applicant receives a decision about granting a patent. Upon entering the information in the Register, any person shall have the right to familiarise himself with it (Law of Ukraine № 3687-XII, 1993).

\section{Discussion}

Like in most European countries, the intellectual property rights protection in the field of medicine and biotechnologies in Ukraine is implemented by means of patenting inventions in this area. At the level of national legislation the patenting issues are regulated by The Law of Ukraine «On Protection of Rights to Inventions and Utility Models». 
In accordance with the signed Ukraine-EU Association Agreement of 2014, the security and protection of intellectual property rights, including the field of medicine and biotechnologies, became one of the key elements. Thus, under the current Ukraine-EU Association Agreement, the protection of intellectual property in the field of medicine and biotechnologies needs harmonization of the national legislation with the requirements of the EU law. At the same time, bringing Ukrainian patent law system of intellectual property protection up to the European standarts demands taking into account the interests of both biotechnology and health care providers, and society as a whole. In the context of the research question, we consider the experience of France to be a positive example, as long as its legistation concerning the legal protection of intellectual property rights, including the field of medicine and biotechnologies, has been codified and presented by The Intellectual Property Code. It must be acknowledged, that Ukrainian law in the field of intellectual property is represented by a large number of laws and by-law regulatory acts, while some issues are even regulated by separate rules of the codes. In this case, it appears to be relevant and substantial to establish a single codified legal act, the rules of which will regulate intellectual property issues in many areas.

\section{Conclusions}

Within the investigated subject matter one highlighted the peculiarities of intellectual property rights protection in the field of medicine and biotechnologies by studying the experience of the leading European countries concerning their government regulation of such issues, as well as legal and organizational aspects providing this protection. In particular, it was found out, that in the United Kingdom the key principles of patenting inventions are stated in The Patents Act of 1977 and specified in The Patents Rules of 2007, which define the detailed patenting procedures. The main official government body responsible for legal protection of inventions in the United Kingdom is The Intellectual Property Office (IPO), which is subordinated to the Department for Business, Innovation \& Skills (BIS). The issues of legal protection of intellectual property in Germany are regulated by two main legal acts: The Patents Act of 1980 and The Patent Costs Act of 2001. The intellectual property rights issues in the field of medicine and biotechnologies are under control of The Patent Office, which is an independent supreme federal authority within the Federal Ministry of Justice and Consumer Protection. The legislation of France, which regulates the issues of the legal protection of intellectual property rights, including the field of medicine and biotechnologies, is presented by The Intellectual Property Code of 1992, The Regulation № 03-07 on patents for the invention of 2003; The Executive Decree № 05-275, which determines the procedure of filing applications and granting patents for the invention of 2005; The Executive Decree № 76-121 on Procedures for Registration and Publication of Geographical Indications and the Establishment of the Relevant Fees of 1976. The legal body responsible for granting patents for inventions is The National Institute of Industrial Property, which is under authority of the Ministry of Economy, Industry and Digital Technologies.

The protection of intellectual property rights in the field of medicine and biotechnologies at the international level is carried out in accordance with the requirements of regulatory legal documents, among which are: the Convention on Biological Diversity of 1992; the European Patent Convention of 1973; the Directive 1998/44/ EC of the European Parliament and of the Council of 1998 on the legal protection of biotechnological inventions; the Convention for the protection of Human Rights and Dignity of the Human Being with regard to the Application of Biology and Medicine: Convention on Human Rights and Biomedicine of 1997; The Agreement on Trade-Related Aspects of Intellectual Property Rights (TRIPS) of 1994 between the members of the World Trade Organization. The international organizations dealing with the protection of intellectual property rights are The World Intellectual Property Organization (WIPO), the European Patent Office (EPO) and the European Union Intellectual Property Office (EUIPO).

Like in most European countries, the intellectual property rights protection in the field of medicine and biotechnologies in Ukraine is also implemented by means of patenting inventions in this area. In particular, the current Ukrainian legislation has got The Law of Ukraine «On Protection of Rights to Inventions and Utility Models» of 1993. The procedure of granting patents for inventions is performed by the Institution in the field of legal protection of invention rights, that is, the State Enterprise «Ukrainian Intellectual Property Institute». 
Therefore, the integration of intellectual capital management system into the current system of economic and legal security of a country, will allow to implement the principles of systematic approach to management and intellectual property protection, to optimize public management resources for the formation and change of legal framework in the field of intellectual property. There will be an opportunity to promptly monitor the effectiveness of brand capital use which will ensure the increase in the level of national legal discipline and strengthening economic and legal security.

\section{References}

Agreement on a Unified Patent Court (2013). URL: https://eur-lex.europa.eu/legal-content/EN/TXT/?uri=CELEX\%3A4201 $3 \mathrm{~A} 0620 \% 2801 \% 29$

Association Agreement between Ukraine, of the one part, and the European Union, the European Atomic Energy Community, and their Member States, of the other part (2014). As amended up to Act of November 30, 2015. URL: https://zakon.rada.gov.ua/laws/show/ ru/984_011

Biotechnology patents at the EPO. The official website of the EPO. URL: https://www.epo.org/news-issues/in-focus/biotechnologypatents.html

Bontis, Nick, (2001). Assessing Knowledge Assets: A review of the models used to measure intellectual capital. International Journal of Management Reviews, 3(1), 41-60.

Chehabeddine, M., Tvaronavičienė, M. (2020). Securing regional development. Insights into Regional Development, $2(1), 430-442$. http://doi.org/10.9770/IRD.2020.2.1(3)

Choo, C.W. and Nick Bontis, (2002). The Strategic Management of Intellectual Capital and Organizational Knowledge, New York: Oxford University Press.

Code de la propriété intellectuelle (1992). As amended up to Act of August 01, 2019. URL: https://www.legifrance.gouv.fr/affichCode. do? cidTexte=LEGITEXT000006069414

Convention on Biological Diversity (1992). URL: https://www.cbd.int/doc/legal/cbd-en.pdf

Convention on Human Rights and Biomedicine (1997). URL: https://rm.coe.int/168007cf98

Danko, T.P., Kiselev, V.M., Chaykovskaya, L.A., Smelov, P.A., Sekerin, V.D., Gorokhova, A.E. (2020). Marketing positioning of countries in the field of innovations: questions and answers. Entrepreneurship and Sustainability Issues, 7(4), 2851-2862. http://doi. org/10.9770/jesi.2020.7.4(18)

Directive 98/44/EC of the European Parliament and of the Council on the legal protection of biotechnological inventions (1998). URL: https:/eur-lex.europa.eu/legal-content/EN/TXT/?uri=celex:31998L0044

Drobyazko, S., Makedon, V., Zhuravlov, D., Buglak, Y., Stetsenko, V. (2019). Ethical, technological and patent aspects of technology blockchain distribution. Journal of Legal, Ethical and Regulatory Issues, Volume 22, Special Issue 2: URL: https://www.abacademies. org/articles/Ethical-Technological-and-patent-aspects-of-technology-blockchain-distribution-1544-0044-22-SI-2-365.pdf

European Patent Convention (1973). URL: https://www.epo.org/law-practice/legal-texts/html/epc/2016/e/EPC_conv_20180401_ en_20181012.pdf

Law of Ukraine № 3687-XII On the protection of inventions and utility models (1993). As amended up to Act of December 05 , 2012. URL: https://zakon.rada.gov.ua/laws/show/3687-12

Lincényi, M., Č́rsky, J. (2020). Policy trusts in public policy in the Slovak Republic. Insights into Regional Development, 2(1), 456468. http://doi.org/10.9770/IRD.2020.2.1(5)

Malhotra, Y. (2003). Managing and measuring knowledge assets in the public sector”, working paper, Syracuse University, Syracuse, New York, NY.

Patentgesetz (PatG) (1980). As amended up to Act of October 08, 2017. URL: https://www.gesetze-im-internet.de/patg/BJNR201170936. html

Reznik, O., Muzychuk, O., Andriichenko, N., Yakushchenko, Y., \& Korzh, S. (2020). Fight Against Doping: Experience of Ukraine and European States. Amazonia Investiga, 9(27), 34-41. https://doi.org/10.34069/AI/2020.27.03.4 
Sagiyeva, R,, Zhuparova, A., Ruzanov, R., Doszhan, R., Askerov, A. (2018). Intellectual input of development by knowledge-based economy: problems of measuring in countries with developing markets, Entrepreneurship and Sustainability Issues 6(2): 711-728. http://doi.org/10.9770/jesi.2018.6.2(17)

Sullivan, P. (2000). Value Driven Intellectual Capital, John Wiley and Sons: Toronto

Sustainable Development Strategy «Ukraine 2020» (2015). URL: https://zakon.rada.gov.ua/laws/show/5/2015

The official website of the European Patent Office (EPO). URL: https://www.epo.org

The official website of the European Union Intellectual Property Office (EUIPO). URL: https://euipo.europa.eu

The official website of the L'Institut national de la propriété industrielle (INAPI). URL: http://e-services.inapi.org

The official website of the World Intellectual Property Organization (WIPO). URL: https://www.wipo.int/about-wipo/en/

The Patents Act (1977). As amended up to Act of July 25, 2018. URL: https://www.gov.uk/guidance/the-patent-act-1977

UK PatLib contact information. URL: https://www.gov.uk/government/publications/uk-patlib-network/uk-patlib-contact-information

WTO: Agreement of Trade-Related Aspects of Intellectual Property Rights (1994). As amended up to Act of December 06, 2005. URL: https://eur-lex.europa.eu/legal-content/EN/ALL/?uri=legissum:r11013

Zeibote, Z., Volkova, T., Todorov, K. (2019). The impact of globalization on regional development and competitiveness: cases of selected regions, Insights into Regional Development 1(1): 33-47. https://doi.org/10.9770/ird.2019.1.1(3)

Alexander BARANOV, Doctor of Law Honored of Science and Techology of Ukraine, Head of the Center for Social and Legal Issues in the sphere of information technologies, products and services

ORCID ID: orcid.org/0000-0003-3233-6687

Vitalii KUCHER, Candidate of Law, Associate Professor, Head of the Department of Civil Law and Procedure Lviv State University of Internal Affairs Lviv

ORCID ID: orcid.org/0000-0003-0877-5735

Olena USTYMENKO, Head of Civil Law Department of Law Faculty V.N. Karazin Kharkiv National University

ORCID ID: orcid.org/0000-0002-1861-8306

Maryna UTKINA, Candidate of Legal Sciences, Sumy State University

ORCID ID: orcid.org/0000-0002-3801-3742

Iryna HRYBACHOVA, Candidate of Legal Sciences, Sumy State University

ORCID ID: orcid.org/0000-0002-5075-5773

This work is licensed under the Creative Commons Attribution International License (CC BY). http://creativecommons.org/licenses/by/4.0/ 